\title{
Planning for Sustainable Development of Tourism in the Tatra National Park Buffer Zone Using the MCDA Approach
}

\begin{abstract}
This study aims to develop practice guidelines for the preparation of local regulations promoting sustainable tourism planning for the area located at the entrance to the Tatra National Park, Poland. Included in the study was a set of tourism activities put forward by the local community. These activities were divided into two priorities: sustainable tourist activities (hiking and walking, cycling, horseback riding) and investments that would have an environmental impact (downhill skiing, recreational infrastructure, commerce, catering). The analysis criteria covered the tourist attractiveness of the area and its suitability for a given activity (benefit), as well as requirements concerning the protection of nature, topographical relief, landscape, and traditional land use (cost). These criteria were evaluated using the Analytic Hierarchy Process (AHP) and summarized using the Weighted Linear Combination (WLC). The results showed the high attractiveness of the area for both priorities. However, due to the area's unique nature, investments having an environmental impact must be limited to the vicinity of the existing built-up areas. The use of MCDA supports decision-making at the local scale, significantly enhances the transparency of the results, and facilitates communication with local communities. The comparison with the current local law provisions showed the shortcomings of the methods used to date when preparing planning instruments.
\end{abstract}

Keywords

Sustainable development $\bullet$ spatial planning $\cdot$ MCDA $\cdot$ AHP $\cdot$ WLC $\cdot$ mountain regions

\section{Introduction}

The buffer zones of national parks and biosphere reserves frequently require the implementation of solutions similar to those used for conservation inside protected areas (Mas 2005). For such areas, it is necessary to have a strategic approach for the development of tourism, allowing for its sustainable development while taking into account the preservation of land values by adapting the solutions to the natural landscape, cultural values and ecological sensitivity (Bo et al. 2012). Sustainability is widely considered as a guiding influence for the development of many natural and valuable areas around the world. It is also often used in goal-oriented spatial planning (e.g. Grossmann 2000, Leitao \& Ahern 2002).

Increasingly, attention is being paid to the need for tourism solutions in terms of sustainable development, based on environmental, socio-cultural, and economic pillars (e.g. Mitchell et al. 2012). The efficiency of buffer zones is dependent on the participation of local communities, and priority should be given to environmental protection and, further, to the benefit of local communities (Wells \& Brandon 1993). Residents are one of the most important interest groups in tourist areas and should play an appropriate role in tourism planning (Ryan 2002, Byrd et al. 2009). A key factor in the development of sustainable tourism is the environmental awareness of local communities, stimulated through appropriate management strategies to increase their
Joanna Adamczyk 주, Piotr Wałdykowski $\mathbb{C}$

Institute of Environmental Engineering, Warsaw University of Life Sciences, Warsaw, Poland e-mail: joanna_adamczyk@sggw.edu.pl e-mail: piotr_waldykowski@sggw.edu.pl

Received: 28 December 2020 Accepted: 24 May 2021 ecological knowledge, encourage a positive attitude towards ecotourism, and develop environmental planning that promotes the affinity of residents with local attractions (Zhang \& Lei 2012).

Sustainable tourism planning in the crowded neighbourhoods of natural resource protection areas incorporates multiple conditions, from environmental to economic or legal ones (Eagles et al. 2002). Providing convincing arguments allows the planners to arrive at decisions by employing a systematic and comprehensive framework while maintaining high transparency (Proctor \& Drechsler 2006, Boroushaki \& Malczewski 2010). In such cases (e.g. Ghorbanzadeh et al. 2019), Multi-Criteria Decision Analysis (MCDA) is widely used for decision support (Malczewski 2006). This offers a set of techniques that allow for the selection of the most suitable solution (or a set of solutions) in the structured analysis of decision-making problems (Boroushaki \& Malczewski 2010, Gamper \& Turcanu 2007). The synergy of the GIS and MCDA tools enables the inclusion of the spatial aspect in the analysis, and substantially facilitates communication among stakeholders in all aspects of the decision-making process (Chakhar \& Martel 2003, Malczewski 2006).

Analytic Hierarchy Process (AHP) is one of the range of methods used within MCDA - for example, VIKOR, TOPSIS, ELECTRE. The advantage of this, for this study, is that AHP includes pairwise comparison of decision criteria to determine 


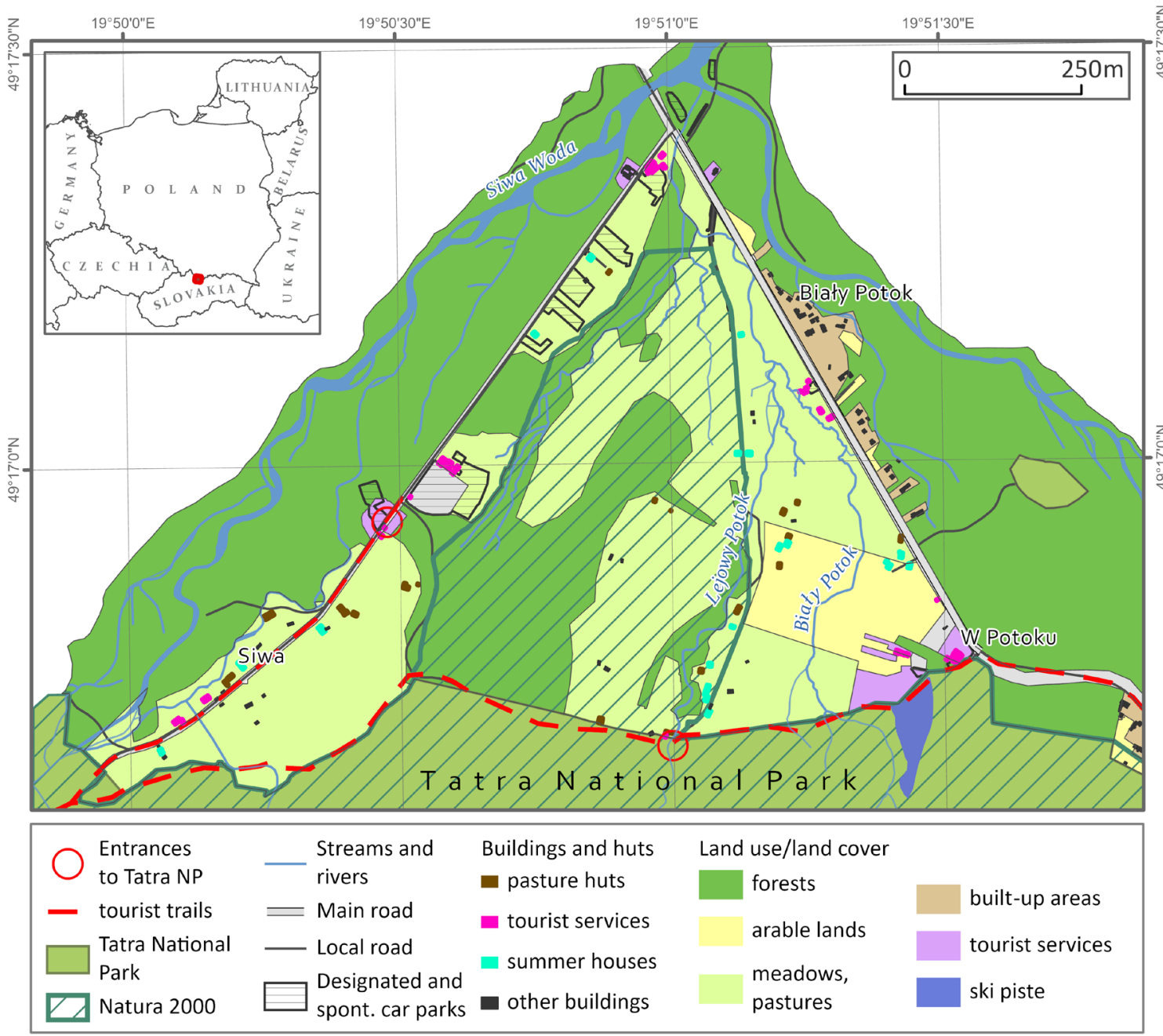

Figure 1. Land use and major issues in the study area Source: own elaboration.

their relative weights (Saaty 1980). In this way, the preferences of different stakeholders can be flexibly incorporated into the planning process (Pavlikakis \& Tsihrintzis 2003). MACBETH is a method that operates using a similar concept. However, this is available with limited software. Combined application of the Analytic Hierarchy Process (AHP) and GIS-MCDA is frequently used in spatial planning and tourism planning (e.g. Gigović et al. 2016, Gourabi \& Rad 2013, Bunruamkaew \& Murayama 2012). The clearly defined methodology allows compromises between different aspects of decision-making to be reached (Feick \& Hall 2001), thus providing important support both in the planning process and in attempts to involve the public in decision-making (Gamper \& Turcanu 2007).

Most of the GIS-MCDA applications in the context of tourism planning are at a regional scale (e.g. Gigović et al. 2016, Ghorbanzadeh et al. 2019). In many of them, the general properties of the area are considered; the analysis does not take into account the trade-off aspect between different stakeholders in the area, while it does select specific land-use alternatives (e.g. Proctor \& Drechsler 2006, Bunruamkaew \& Murayama 2012). We have not found any studies that have been directly applied to tourism planning practice with recommendations for relevant planning documents.
The aim of this study was to develop good practice for the preparation of local sustainable tourism planning legislation. For this purpose, GIS-MCDA together with AHP was selected as one of the most transparent methods that can be applied to tourism planning in a situation of compromise between natural conditions and the needs of tourists and local communities. The work presented is carried out on a detailed scale linking natural resources and local planning conditions. Under two priorities sustainable tourism and activities requiring significant investments - we focus on the suitability of the area for specific activities and investments. The objective is to develop recommendations for the upcoming version of the local spatial development plan.

\section{Materials and methods}

Study area

The study area is located in the Polish Carpathians in the buffer zone of Tatra National Park (TNP), designated as a UNESCO World Biosphere Reserve in 1992. The area is part of the northern foothills of the Tatra Mountains. The region under analysis (Figure 1) forms a triangle that covers an area of 2.66 square kilometres between two popular entrances to the TNP (Kościelisko Valley and Chochołowska Valley). A regional road 
closes the area from the north and allows direct access from two cities, Zakopane and Krakow.

According to TNP (2020), in recent years the Tatra National Park has been visited by more than six million tourists per year, and the trend is increasing. The area is attractive due to the views of the Tatra Mountains and the seasonal flowering of spring crocus (Crocus scepusiensis). Most of the traditional agricultural landscape has been preserved here (arable land and pastures - $29 \%$, forest complexes $-60 \%$ ). Visitors are also attracted by the cultural value of the area, as the traditional pastoral economy and architecture of Podhale have been preserved. From a topographical point of view, the area is characterized by small slopes and is crossed by several watercourses. The central part of the area is protected under the Natura 2000 network (Polana Biały Potok PLH120026).

Numerous phenomena threatening the natural, landscape, and cultural values are being observed in this region because of the high investment potential of the area. Due to its gentle terrain, the area is favourable for tourist development and investments that may significantly affect the landscape. In the SE part of the area, there is a small downhill skiing centre with a concentration of tourist services. Important zones currently under investment pressure are the surroundings of the road connecting the development area with Zakopane (main road) and the road leading to one of the entrances to the national park (local road). The main problems resulting from uncontrolled investments in the area may be the formation of spontaneous parking lots, the development of buildings aimed at mass tourism for visitors to the Tatra Mountains (tourist services), and the building of structures that would not be relevant to the cultural landscape of the region (summer houses, other buildings). We can assume that appropriate management would reduce the tourist traffic from the overexploited Tatra National Park and increase the interest of tourists in the areas surrounding it (Skawiński 2010).

\section{GIS Multi-criteria Decision Analysis (GIS-MCDA)}

The research procedure (Figure 2 ) conducted to investigate the real conditions for undertaking tourist activities and investment projects in the study area was as follows: Prior to the analysis, a survey of local conditions was conducted within the framework of a summer school Summer School 'Landscape planning in tourist attraction areas - Zakopane and Tatra National Park' (Kościelisko 15-24.07.2016).. The field study covered the following topics: assessing tourist attractiveness of the area, tourist pressure, social context of nature conservation and spatia planning. On this basis, a land suitability analysis was carried out individually for each activity postulated by the interest groups in the area. The proposed uses of land were divided into two groups, with sustainable development in mind (Sobala \& MygaPiatek 2016): (1) sustainable tourist and recreation activities with a minor impact on the natural environment (hiking, recreational walking, horse riding); and (2) activities with a significant impact on the environment, requiring investments (recreation zones, skiing, local economic initiatives - commerce and catering zones, local services zones, car parking spaces).

The main steps of the analysis employed the MCDA method (Malczewski 1999). It offers a set of techniques that allow for the selection of the most suitable solution (or set of solutions) in a structured analysis of decision-making problems (Malczewski 2006, Gamper \& Turcanu 2007). Criteria weighting was performed using the AHP method (Saaty 1980). Subsequently, the criteria and their weights were subjected to the Weighted Linear Combination (WLC), which is the most commonly used MCDA method of criteria aggregation (Malczewski 2000, Malczewski 2006). The resulting land suitability maps for each activity were combined in a synthesis map, which divided the study area into zones with uniform recommendations for their development. The results of the study were then compared with the local regulations governing specific areas for the activities and investments in question. As a result, the weaknesses of the existing legislation were identified and recommendations for the preparation of the current Local Plan of Spatial Development were formulated.

\section{Decision criteria and data}

The criteria for the analysis were established based on the local conditions for defined models of use that have been described above. Two groups of criteria were considered: (1) site attractiveness (benefit) - understood as a set of site-specific features that are appreciated by visitors, including natural, landscape and cultural attractions and topographical and land cover conditions, which influence tourists' preferences and determine both the technical conditions for practising activities and the location of general tourism infrastructure; and 2) limitations (cost) - area features that comply with the requirements to protect nature, topographical relief, landscape, and traditional land use. The conditions presented in Table 1 served as a basis for multicriteria analysis. When assessing the importance of the criteria for each activity in Table 1, the principle of the sustainable use of natural resources was followed to ensure ecological connections within the environmental system of the municipality.

In the criteria group of land attractiveness for tourism and investment, the visitor's perception of the land's attractiveness was considered. The scope of the criteria is related to the specificity of the area and includes the existing recreational and sightseeing attractions and the landform.

The components of the criteria related to the terrain shape (Table 1) were determined as follows. The terrain slope was calculated for the Digital Elevation Model (DEM) of the study site. The raster was then reclassified into two slope classes relevant to the activities in question. The river bottoms and stream valleys were identified using a geomorphologic topographic map and DEM analysis. The range of the forest coincided with the range of wide valley bottoms. Then, buffers with a width of 15 metres were determined around the banks of other streams, according to the recommendations recorded in the local planning document (SUIKZP 2015).

In the group of criteria concerning nature and landscape conservation (Table 1), the major spatial limitations of the development of the discussed activities are given. These restrictions are necessary to protect the areas for natural reasons. They are also aimed at preserving the existing landscape character and preventing its degradation.

The land cover data, being the basis for many criteria, were obtained from the maps provided by local authorities (SUIKZP 2015). The boundaries of areas with a single designation, being planning units, were used for this purpose. Topography criteria, including visual assessment, were derived from the Digital Elevation Model (DEM) and Digital Surface Model (DSM) and obtained with $15 \mathrm{~m}$ resolution based on ALS (Airborne Laser Scanning) obtained from the National Geodetic and Cartographic Resource (GUGiK 2016).

\section{Criteria value assessment and scaling}

The criteria were transformed in order to bring them down to workable units (Malczewski 2000) and evaluated in terms of compliance with analysis goals. In this way, the value functions presented in Table 1 were determined. Preferences of decisionmakers and stakeholders (involved in the workshops held as part of the summer school and moderated by academic experts) with regard to these values were identified using the expert method from the point of view of anticipated activities. An aspect of the 


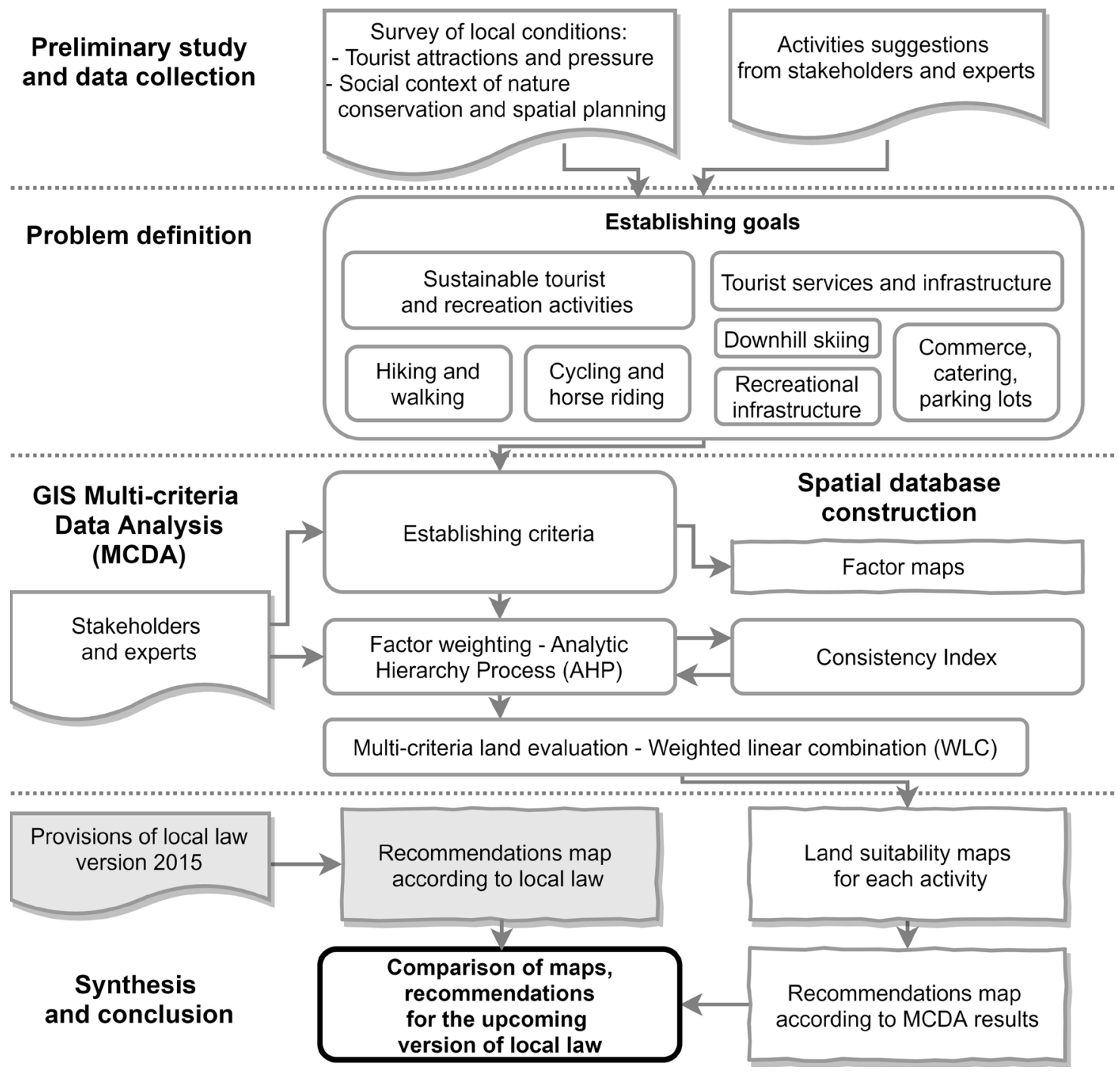

Figure 2. The analysis workflow

Source: own elaboration

tourist development of the area, namely its attractiveness and limitations concerning tourist and recreational activities, as well as infrastructure construction, was assessed. The interpretation of the land's characteristics depends on the type of planned activity; the premises for assessment are described above. According to those factors, the criteria were divided into two groups: benefits - whose higher values are beneficial for the analysis objectives; costs - which introduce significant restrictions on the planned ventures.

The criteria specified in Table 1 were subjected to value scaling, using the maximum score procedure in the range of $0-1$, thus reducing them to comparable and quantitative categories. As the criteria were mostly qualitative, their ranges were treated as single terrain features. The quantitative indicators, such as the slope and visual exposure zones, were also divided into discrete categories suitable for evaluation.

\section{Criteria weighting}

In the next step of the study, the criteria were assigned weights based on expert assessments of the specificity of the studied area. This phase was also carried out as part of the workshop mentioned above. The evaluation was carried out through pairwise comparison within the analytic hierarchy process (AHP) (Saaty 1980), which allowed the expert assessment to be translated into documented scores by forcing the comparison of individual criteria and requiring consistency of the assessment.

During the assessment, the most frequently used scoring according to Saaty (1994) (1 - equal weight, 3 - moderately more important, etc.) was abandoned in favour of compromise values 1,2 , and 3 . The experts indicated relatively small differences in the importance of the criteria. For pairwise comparison, we applied the most frequently used method (Malczewski 2006) of obtaining factor weights by averaging normalized judgement values (Saaty 1980). To check the level of coherence for the paired comparisons, the weight consistency ratio $(C R)$ was calculated according to a formula defined by Saaty (1980). Concerning the Random Consistency Index, for six factors the value 1.25 was taken, based on the recommendation of Saaty \& Ozdemir (2003). In this case, the consistency coefficient had a value of 0.02 , which, given that it should be $C R<0.10$, was a reasonable result. 
Table 1. Decision criteria value scaling: benefit criteria: $0-1$ - the closer to 1 the more positive the meaning of the criterion, $0-$ the irrelevant criterion; cost criteria: 0-1 - the closer to 1 the greater the restriction caused by the criterion; EXCL - criterion excluded from the analysis due to the nature of the discipline; NE - not evaluated in the case of downhill skiing. The numbers (1-6) refer to the categories listed in Table 2

\begin{tabular}{|c|c|c|c|c|c|c|c|}
\hline \multirow[b]{2}{*}{ Groups } & \multirow{2}{*}{\multicolumn{2}{|c|}{ Criteria }} & \multicolumn{2}{|c|}{ Sustainable activities } & \multicolumn{3}{|c|}{ Projects requiring investments } \\
\hline & & & $\begin{array}{c}\text { Hiking and } \\
\text { walking }\end{array}$ & $\begin{array}{l}\text { Cycling and } \\
\text { horseback } \\
\text { riding }\end{array}$ & $\begin{array}{l}\text { Downhill } \\
\text { skiing }\end{array}$ & $\begin{array}{l}\text { Recreational } \\
\text { infrastructure }\end{array}$ & $\begin{array}{l}\text { Commerce, } \\
\text { catering, } \\
\text { parking lots }\end{array}$ \\
\hline \multicolumn{8}{|c|}{ Land attractiveness and suitability for tourism and investment projects (benefit) } \\
\hline \multirow{4}{*}{$\begin{array}{c}\text { Tourism } \\
\text { attractions } \\
\text { (1) }\end{array}$} & \multicolumn{2}{|c|}{$\begin{array}{l}\text { Environmental: crocus scepusiensis - } \\
\text { frequent and widespread appearance }\end{array}$} & 1 & 1 & 0 & 1 & 0.2 \\
\hline & \multicolumn{2}{|c|}{ Scenic values: visibility of the Tatra peaks } & 1 & 1 & 0.8 & 1 & 0.4 \\
\hline & \multicolumn{2}{|c|}{$\begin{array}{c}\text { Scenic values - contrasting land cover: } \\
\text { zone } \\
\text { of } 150 \mathrm{~m} \text { between forest and lower land } \\
\text { cover }\end{array}$} & 0.8 & 0.8 & 0.8 & 1 & 0.2 \\
\hline & \multicolumn{2}{|c|}{$\begin{array}{l}\text { Cultural: occurrence of traditional } \\
\text { architecture }\end{array}$} & 1 & 1 & 0.8 & 1 & 1 \\
\hline \multirow{6}{*}{$\begin{array}{l}\text { Land } \\
\text { cover/use } \\
\text { suitability } \\
(2)\end{array}$} & \multicolumn{2}{|l|}{ Forest } & 1 & 1 & 0 & 1 & 0.2 \\
\hline & \multicolumn{2}{|c|}{ Meadows and pastures } & 1 & 1 & 0.8 & 1 & 0.2 \\
\hline & \multicolumn{2}{|c|}{ Arable lands } & 0.8 & 0.8 & 1 & 0 & 0.2 \\
\hline & \multicolumn{2}{|c|}{ Built-up areas and tourism services } & 0.6 & 0.6 & EXCL & 1 & 1 \\
\hline & \multicolumn{2}{|c|}{ Proximity of roads $6-20 \mathrm{~m}$} & 0.8 & 0.8 & EXCL & 1 & 1 \\
\hline & \multicolumn{2}{|c|}{ Proximity of roads up to $6 \mathrm{~m}$} & 0.6 & 0.6 & EXCL & 0 & 0.8 \\
\hline $\begin{array}{l}\text { Flat areas } \\
\quad(6)\end{array}$ & \multicolumn{2}{|c|}{ Flat areas and slight terrain slope $\left(<2.9^{\circ}\right)$} & 1 & 1 & EXCL & 1 & 1 \\
\hline \multicolumn{8}{|c|}{ Limitations on the development of tourism and investment (cost) } \\
\hline \multirow{2}{*}{$\begin{array}{l}\text { 3. Nature } \\
\text { and } \\
\text { landscape } \\
\text { protection } \\
\text { (3) }\end{array}$} & \multicolumn{2}{|c|}{$\begin{array}{c}\text { Natura } 2000 \text { - ecological corridor } \\
\text { protection }\end{array}$} & 0.2 & 0 & 1 & 0 & 1 \\
\hline & \multicolumn{2}{|c|}{$\begin{array}{l}\text { Preservation of traditional land uses: } \\
\text { meadows and pastures, forests outside the } \\
\text { Natura } 2000 \text { area, arable lands }\end{array}$} & 0 & 0 & 0.4 & 0 & 0.8 \\
\hline \multirow{2}{*}{$\begin{array}{l}\text { 4. Scenic } \\
\text { value (4) }\end{array}$} & \multirow{2}{*}{$\begin{array}{l}\text { Areas with landform and } \\
\text { traditional use, creating } \\
\text { scenic value }\end{array}$} & $\begin{array}{c}\text { areas visible } \\
\text { from } 10-32 \\
\text { observer points }\end{array}$ & 0 & 0 & 0.6 & 0.2 & 0.6 \\
\hline & & $\begin{array}{l}32+\text { observer } \\
\text { points }\end{array}$ & 0 & 0 & 0.8 & 0.4 & 0.8 \\
\hline \multirow{3}{*}{$\begin{array}{l}\text { 5. Erosion } \\
\text { and } \\
\text { flooding } \\
\text { risk (5) }\end{array}$} & \multicolumn{2}{|c|}{ Faint $\left(2.9-9^{\circ}\right)$ and moderate $\left(>9^{\circ}\right)$ slope } & 0.2 & 0.6 & NE & 0.6 & 0.8 \\
\hline & \multicolumn{2}{|c|}{ Main rivers valley floors } & 0.2 & 0.2 & EXCL & 0.4 & 1 \\
\hline & \multicolumn{2}{|c|}{ Stream valleys with a surrounding of $15 \mathrm{~m}$} & 0.4 & 0.8 & EXCL & 1 & 1 \\
\hline
\end{tabular}

Source: own elaboration

Criteria combination

The nature of the used criteria and input data resulted in the choice of Weighted Linear Combination (WLC) as the method to summarize criteria values (Rinner \& Voss 2013). This technique is compensatory - the summarized impact of all the criteria was the basis for the decision; multi-attribute - as the land-use suitability was analysed; and discrete and spatially explicit - this kind of information is most useful as the basis for land-use planning.
The multi-criteria analysis (MCDA) was carried out using the MCDA4ArcMap tool (Rinner \& Voss 2013), which is an add-on to the ArcMap program for the analysis of numerical data available in Shapefile vector layer attribute tables. This enabled input data normalization strategies to be selected, from which the maximum score normalization was used (Rinner \& Voss 2013). 
Table 2. Criteria weights matrix: 1, 2, 3-judgment values, 1/2, 1/3-reverse values. Numbers 1-6 refer to the categories presented in Table 1

\begin{tabular}{|c|c|c|c|c|c|c|c|}
\hline Criteria groups & $\mathbf{1 .}$ & $\mathbf{2 .}$ & $\mathbf{3 .}$ & $\mathbf{4 .}$ & $\mathbf{5 .}$ & $\mathbf{6 .}$ & $\begin{array}{c}\text { Factor } \\
\text { weights }\end{array}$ \\
\hline 1. Tourism attractions & 1 & 2 & 1 & 3 & 2 & 3 & $\mathbf{0 . 2 7}$ \\
\hline 2. Land cover/use suitability & $1 / 2$ & 1 & $1 / 2$ & 2 & 1 & 2 & $\mathbf{0 . 1 4}$ \\
\hline $\begin{array}{c}\text { 3. Nature and landscape } \\
\text { protection }\end{array}$ & 1 & 2 & 1 & 3 & 2 & 2 & $\mathbf{0 . 2 7}$ \\
\hline 4. Scenic value & $1 / 3$ & $1 / 2$ & $1 / 2$ & 1 & $1 / 3$ & 1 & $\mathbf{0 . 0 8}$ \\
\hline 5. Erosion and flooding risk & $1 / 2$ & 1 & $1 / 2$ & 2 & 1 & 3 & $\mathbf{0 . 1 4}$ \\
\hline 6. Flat areas & $1 / 3$ & $1 / 2$ & $1 / 2$ & 1 & $1 / 3$ & 1 & $\mathbf{0 . 0 8}$ \\
\hline
\end{tabular}

Source: own elaboration

Final results classification

The WLC results for all the criteria were summarized in the land suitability map, which was to provide recommendations on the use of particular parts of the land for the anticipated activities. For this purpose, sites meeting the positive suitability criterion were selected from the WLC result layers. The following principles were followed: (1) for sustainable tourism activities, areas classified as highly attractive/suitable and suitable were selected - the suitable with limitations class was also taken into account, as the requirements to be met in an area falling within this class were realistic, for example the limitation of free forest penetration in the Natura 2000 area; (2) for downhill skiing, only the suitable with limitations class was applicable - the extent of these areas was further limited to areas that offered sufficient space to locate a downhill track of at least $300 \mathrm{~m}$ in length and they were located in the immediate proximity of roads; (3) for activities requiring investment, only areas in the highly attractive/ suitable and suitable classes were selected due to their expected environmental and landscape impact.

A map containing 12 areas with separate categories of permitted use was compiled from these layers to serve as a recommendation for the upcoming edition of Local Plan of Spatial Development. This result was then compared with the map prepared on the basis of the provisions of the current Local Plan of Spatial Development (SUIKZP 2015). The necessary changes in the process of preparing such documents were indicated and taken into account while preparing the new version.

\section{Results}

The results of the criteria assessment are presented in Table 1. Based on the evaluation shown in this table, and on the criteria weighting (Table 2), we compiled the land suitability map (Figure 3). This was prepared to provide recommendations on the use of particular parts of the land for the anticipated activities.

The following priorities (Table 2) were set forth for the criteria weighting procedure at three levels of importance: (1) criteria of utmost importance that define the specificity of the studied area (a) natural resource and landscape attractions most appreciated by tourists, and (b) areas at risk of erosion and flooding, which are the most important in the group of cost criteria, as the study site is subject to the processes taking place at the foot of the mountain massif; (2) important criteria resulting from practical rationale concerning land use - (a) favourable land cover/ use, which determines the preferences of tourists or investors, (b) natural resource and landscape protection areas; (3) less important criteria - (a) the landform suitable for investments, (b) preservation of the scenic attractiveness of the landscape.

The studied area is highly attractive for all the discussed disciplines of active tourism and for locating recreation infrastructure. It may be interesting for tourists either as an entrance zone to the Tatra National Park or as an activity area outside the TNP. Among the tourist values, it is particularly worthwhile distinguishing large areas of forest and still-preserved traditional land use. The latter feature distinguishes the study area among many other areas located at the foot of the Tatra Mountains. The site is also attractive for investment in tourismrelated infrastructure, due to its visual qualities and the low proportion of steep slopes. From a technical point of view, the most suitable areas are those adjacent to existing roads and traditional buildings.

Nature and landscape protection limitations are quite considerable here, which has significantly contributed to the results presented in Figure 3. These constraints are mainly determined by erosion and the flood risk posed by streams, whose beds cover a significant study area, including almost half the forests. Undertaking investments involving the construction of buildings here is excluded or significantly restricted. The same applies to places with significant slopes. There is also a need to provide additional protection for the designated tourist trails here. The large, central part of the area has a Natura 2000 status, which limits the free penetration of forests and excludes investment in infrastructure. In forest areas, it is mainly the restrictions placed on walking on existing roads that are important.

Analysis results regarding the location of ski infrastructure and downhill runs demonstrate that this area is practically unsuitable for such activities. Above all, it is difficult to find slopes suitable for advanced skiers. Considering all the restrictions on investment, one compact area can be found for beginner skiers to locate a route of at least 200 metres in length. This may be suitable for the location of a ski school. This area adjoins the already existing ski infrastructure in the eastern part of the site. This was considered, upon the request of local people, to identify a zone suitable for such investments.

The limitations related to nature and landscape conservation allowed a limited number of zones for sustainable recreational and tourism infrastructure investment projects. These zones are located along roads, in the proximity of buildings, and on the Biały Potok Glade, where traditional buildings are located. It is important to stipulate here that the constructed buildings must not affect the landscape values of the area - their volume and 


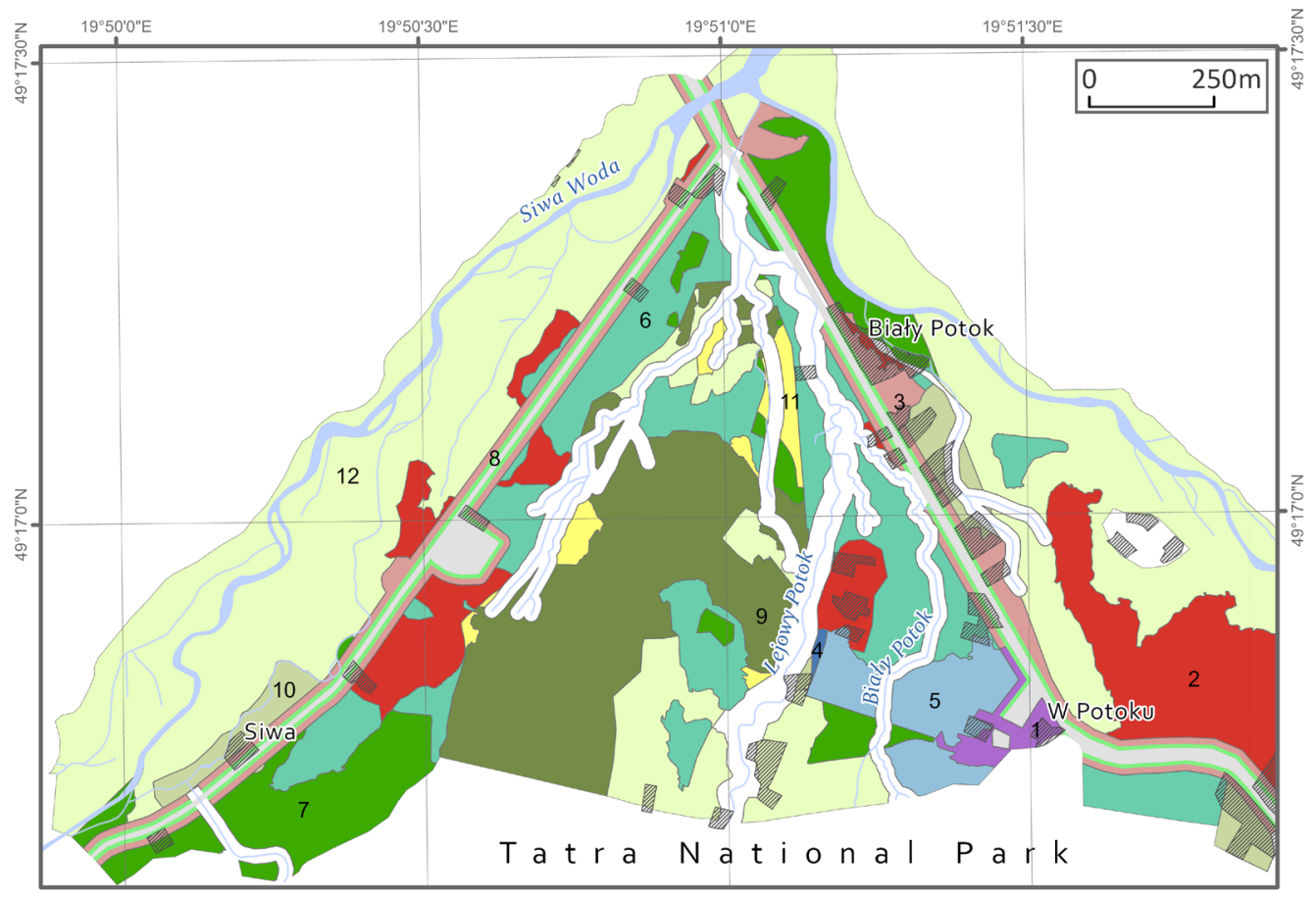

\begin{tabular}{|c|c|}
\hline Land Suitability & 7 hiking and walking, cycling and horse \\
\hline \multirow{2}{*}{$\begin{array}{l}\text { commerce, downhill skiing, hiking and } \\
\text { walking, cycling and horse riding }\end{array}$} & \\
\hline & 8 cycling and horse riding \\
\hline \multirow{2}{*}{$\begin{array}{l}\text { commerce, recreational infrastructure, } \\
\text { hiking and walking, cycling and horse } \\
\text { riding }\end{array}$} & 9 hiking and walking with limitations \\
\hline & 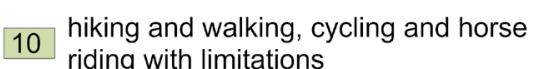 \\
\hline $\begin{array}{l}\text { commerce, hiking and walking, cycling } \\
\text { and horse riding }\end{array}$ & 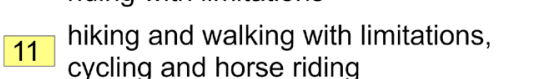 \\
\hline $\begin{array}{l}\text { downhill skiing, recreational } \\
\text { infrastructure, hiking and walking, cycling } \\
\text { and horse riding }\end{array}$ & 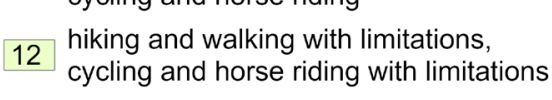 \\
\hline $\begin{array}{l}\text { downhill skiing, hiking and walking, } \\
\text { cycling and horse riding }\end{array}$ & $\begin{array}{l}\text { Streams and rivers } \\
\text { Transportation areas }\end{array}$ \\
\hline \multirow{2}{*}{$\begin{array}{l}\text { recreational infrastructure, hiking and } \\
\text { walking, cycling and horse riding }\end{array}$} & Built-up areas \\
\hline & Areas excluded from analysis \\
\hline
\end{tabular}

Figure 3. Land suitability analysis results shown for analyzed activities Source: own elaboration

style should be compatible with traditional Podhale architecture. Access to the area must also be provided via existing roads.

The use of land for car parks is a separate investment group. This is an important element both for sustainable activities as well as for when the land is designated for investment. Due to significant environmental interference, the location of car parks should be limited to the immediate surroundings of the roads (up to $20 \mathrm{~m}$ ), and only in close proximity to existing buildings or other areas intended for tourist investments.

The planning conditions (Figure 4) define the area as generally suitable for tourist activities and for locating tourist infrastructure. Attention needs to be drawn to the non-specific provisions for active tourism and the location of recreational facilities for all areas, except transport and built-up areas. Since tourism in this area is becoming more popular and the number of tourists is increasing, the lack of regulations in this respect may result in a significant threat to its values. The same applies to the skiing infrastructure that is permitted everywhere, even in unsuitable areas. A particular paradox is that no restrictions are imposed on the Natura 2000 areas. Only the location of the tourist infrastructure facilities has been significantly limited in the planning records. Additionally, except for the streams, neither landscape features nor topography has been taken into account in the provisions.

\section{Discussion and conclusions}

This study shows that the conditions for sustainable tourism development exist in the studied area. The study results provide the basis for the development of land-use projects aimed the promotion of active tourism. Another practical conclusion is that the tourist pressure in the entrance areas of the Tatra valleys can be reduced by promoting adjacent areas, bearing in mind that the development of commercial facilities should be limited to the immediate vicinity of road infrastructure and buildings. 


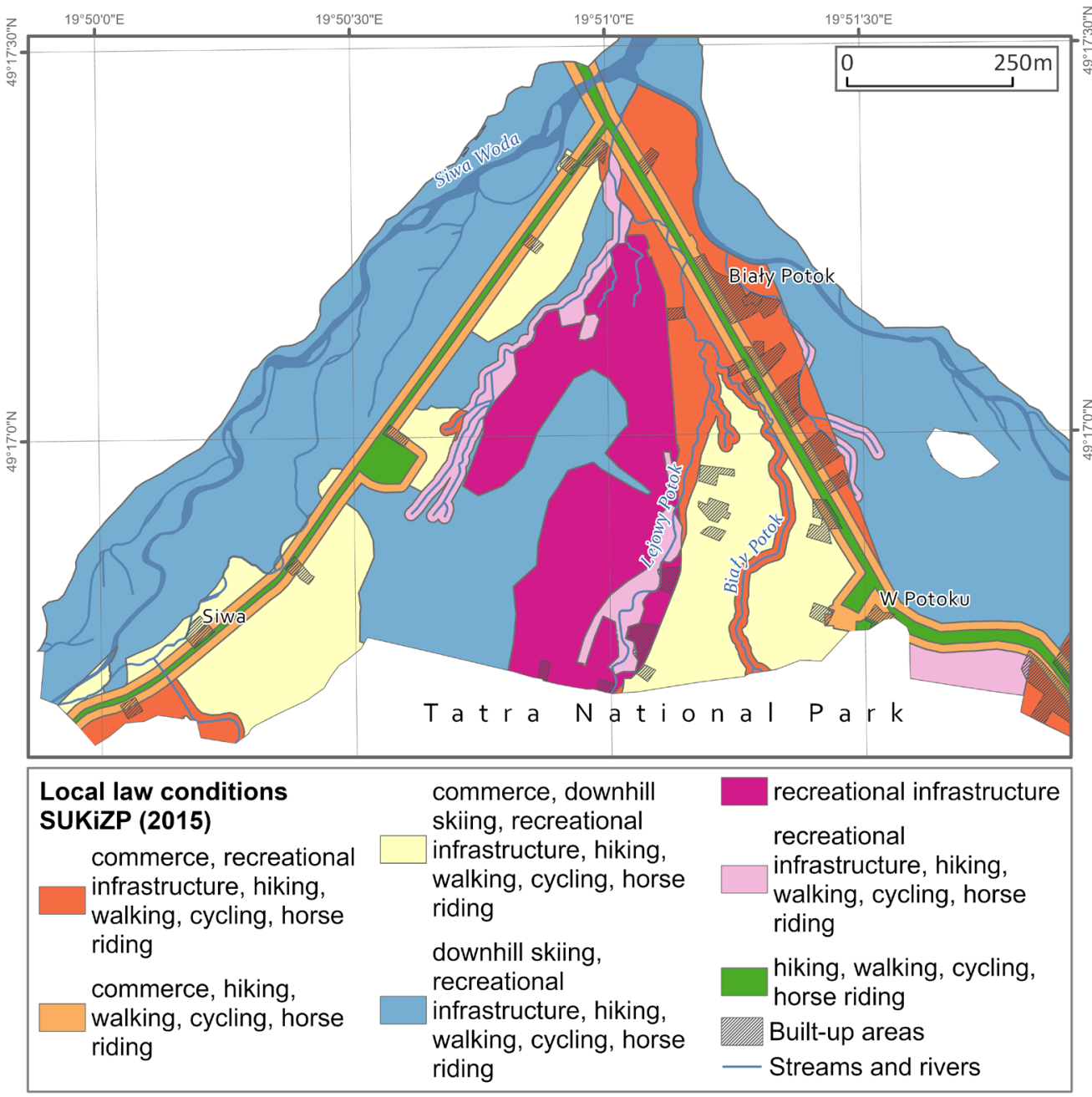

Figure 4. Land suitability maps showing spatially related provisions of local law. Source: own elaboration based on Local Plan of Spatial Development (SUIKZP 2015)

The authors of this study consider this area unsuitable for the development of ski infrastructure.

The advantages of combining GIS-MCDA, AHP and WLC methods include the improved accuracy and clarity of the results, and a logical and transparent decision-making process. This approach allowed quite a large number of criteria to be applied to make comprehensive decisions on the basis of a compromise between two main land-use priorities: sustainable tourism and investments in general tourism infrastructure. Most studies applying MCDA refer to very general criteria, not always adequate to the appropriate detailed scale (e.g. applied in natural sciences, tourism planning, and spatial planning). In this study, an attempt was made to adjust the scope of the analysis for practical purposes, and to provide a contribution to the discussion on the practical aspects of the use of the MCDA method.

When preparing the data base, the authors took care to support the transparency of the results by making the data used legible. The land use/land cover classes used were based on units contained in the planning documents (SUIKZP 2015) so that the conclusions from this work could be directly implemented in forthcoming planning documents - another advantage of avoiding the Modifiable Areal Unit Problem (MAUP) (Openshaw 1984, Jelinski \& Wu 1996). Although this led to the generalization of boundaries of land cover objects - for example forest - it remains a standard practice in a strategic study such as the Local Plan of Spatial Development. In further work, these results need to be extended with more specific activities postulated in the study area, especially other types of recreational infrastructure and the location of parking lots. In order to develop more detailed documents, such as a specific land development plan on a sitescale (1:1000), the analysis results should be further elaborated by introducing additional natural resource criteria and land ownership structure. The proposed framework for developing planning documents was based on a workshop approach involving selected land-use proposals. Therefore, it would be advisable to expand the group of experts involved in the final study according to the scope of the planned activities.

The potentially weakest part of the MCDA analysis described above may be the use of the AHP method for criteria weighting. The limitations of this method (e.g. Weber et al. 1988, Saaty 1994, Karbhari 1994) should be considered while interpreting the results. Despite these limitations, AHP is recommended as a method with very high utility values, allowing a problem to be structured that is complex due to the overlapping of different needs and visions represented by interest groups. It provides a basis for achieving convincing results that take into account the diverse perspectives 
of the stakeholders (Feick \& Hall 2001). Furthermore, it allows for the presentation of qualitative opinions in quantitative terms. Interactive analysis is indicated as a way to avoid problems related to human perception and subjectivity (Gamper \& Turcanu 2007).

The example of the local community's pressure on investments with a significant impact on the environment, which could threaten the natural, landscape and cultural values of the study area, shows how crucial it is to base the spatial planning process on clear and defendable arguments. The authors hope that the MCDA methodology demonstrated in this study will become a practice in the development of local law, and that its application will contribute to building the environmental awareness of the local community by providing insight into the potential consequences of the investments undertaken.

\section{Acknowledgements}

The authors would like to thank Agata Cieszewska PhD and the participants of Summer School 'Landscape planning in tourist attraction areas - Zakopane and Tatra National Park' (Kościelisko 15-24.07.2016) for sharing the results of field studies and cameral analyses.

\section{ORCID}

Joanna Adamczyk (D) https://orcid.org/0000-0002-8026-2734

Piotr Wałdykowski (D) https://orcid.org/0000-0002-7493-6405

\section{References}

Bo, L, Zhang, F, Zhang, L-W, Huang, J-F, Zhi-Feng, J \& Gupta, D 2012, 'Comprehensive suitability evaluation of tea crops using GIS and a modified land ecological suitability evaluation model', Pedosphere, vol. 22, no. 1, pp. 122-130.

Boroushaki, S \& Malczewski, J 2010, 'Measuring consensus for collaborative decision-making: A GIS-based approach. Computers', Environment and Urban Systems, vol. 34, no. 4, pp. 322-332.

Bunruamkaew, K \& Murayama, Y 2012, 'Land use and natural resources planning for sustainable ecotourism using GIS in Surat Thani, Thailand', Sustainability, vol. 4, no. 3, pp. 412-429.

Byrd, ET, Cardenas, D \& Dregalla, S 2009, 'Differences in stakeholder attitudes of tourism development and the natural Environment', E-Review of Tourism Research, vol. 7, no. 2, pp. 39-51.

Chakhar, S \& Martel, JM 2003, 'Enhancing geographical information systems capabilities with multi-criteria evaluation functions', Journal of Geographic Information and Decision Analysis, vol. 7, no. 2, pp. 47-71.

Eagles, PF, McCool, SF, Haynes, CD \& Phillips, A 2002, 'Sustainable tourism in protected areas: Guidelines for planning and management', Best Practice Protected Area Guidelines Series, no. 8

Feick, RD \& Hall, GB 2001, 'Balancing consensus and conflict with a GIS-based multi-participant, multi-criteria decision support tool. GeoJournal, vol. 53, no. 4, pp. 391-406.

Gamper, CD \& Turcanu, C 2007, 'On the governmental use of multi-criteria analysis', Ecological Economics, vol. 62, no. 2, pp. 298-307.

Ghorbanzadeh, O, Pourmoradian, S, Blaschke, T \& Feizizadeh, B 2019, 'Mapping potential nature-based tourism areas by applying GIS-decision making systems in East Azerbaijan Province, Iran', Journal of Ecotourism, vol. 18, no. 3, 261283.

Gigović, L, Pamučar, D, Lukić, D \& Marković, S 2016, ‘GIS-Fuzzy DEMATEL MCDA model for the evaluation of the sites for ecotourism development: A case study of "Dunavski ključ" region, Serbia', Land Use Policy, vol. 58, pp. 348-365.

Gourabi, BR \& Rad, TG 2013, 'The analysis of ecotourism potential in Boujagh wetland with AHP method', Life Science Journal, 10, no. 2, pp. 251-258.

Grossmann, WD 2000, 'Realising sustainable development with the information society - the holistic double gain-link approach', Landscape and Urban Planning, vol. 50, no. 1-3, pp. 179-193.

GUGiK 2016 - Główny Urząd Geodezji i Kartografii [Head Office of Geodesy and Cartography], Available from: <http://www. gugik.gov.pl/pzgik>. [4 May 2021].
Jelinski, DE \& Wu, J 1996, 'The modifiable areal unit problem and implications for landscape ecology', Landscape Ecology, vol. 11, no. 3, pp. 129-140.

Karbhari, VM 1994, 'The analytic hierarchy process: a viable decision tool for composite materials?', International Journal of Technology Management, vol. 9, no. 1, 77-93.

Leitao, AB \& Ahern, J 2002, 'Applying landscape ecological concepts and metrics in sustainable landscape planning' Landscape and Urban Planning, vol. 59, no. 2, 65-93.

Malczewski, J 1999, GIS and multicriteria decision analysis, John Wiley \& Sons.

Malczewski, J 2000, 'On the use of weighted linear combination method in GIS: common and best practice approaches', Transactions in GIS, vol. 4, no. 1, pp. 5-22.

Malczewski, J 2006, 'GIS-based multicriteria decision analysis: a survey of the literature', International Journal of Geographical Information Science, vol. 20, no. 7, pp. 703-726.

Mas, JF 2005, 'Assessing protected area effectiveness using surrounding (buffer) areas environmentally similar to the target area', Environmental Monitoring and Assessment, vol. 105 , pp. $69-80$.

Mitchell, R, Wooliscroft, B \& Higham, J 2013, 'Applying sustainability in National Park Management: Balancing public and private interests using a sustainable market orientation model', Journal of Sustainable Tourism, vol. 21, no. 5 , pp. $695-715$

Openshaw, S 1984, 'The modifiable areal unit problem', Concepts and Techniques in Modern Geography, no. 8.

Pavlikakis, GE \& Tsihrintzis, VA 2003, 'A quantitative method for accounting human opinion, preferences and perceptions in ecosystem management', Journal of Environmental Management, vol. 68, no. 2, pp. 193-205.

Proctor, W \& Drechsler, M 2006, 'Deliberative multicriteria evaluation' Environment and Planning C: Government and Policy, vol. 24, no. 2, pp. 169-190.

Rinner, C \& Voss, S 2013, 'MCDA4ArcMap-an open-source multi-criteria decision analysis and geovisualization too for ArcGIS 10', Cartouche, Newsletter of the Canadian Cartographic Association, vol. 86, pp. 12-13.

Ryan, C 2002, 'Equity, management, power sharing and sustainability-issues of the "new tourism" Tourism Management, vol. 23, no. 1, pp. 17-26.

Saaty, TL 1980, 'The analytic hierarchy process (AHP)', The Journal of the Operational Research Society, vol. 41, no. 11 pp. 1073-1076.

Saaty, TL 1994, 'Highlights and critical points in the theory and application of the analytic hierarchy process', European Journal of Operational Research, vol. 74, no. 3, pp. 426447. 
Saaty, TL \& Ozdemir, MS 2003, 'Why the magic number seven plus or minus two', Mathematical and Computer Modelling, vol. 38, no. 3-4, pp. 233-244.

Skawiński, P 2010, 'Zarządzanie ruchem turystycznym w Tatrzańskim Parku Narodowym' ['Tourist traffic management in the Tatra National Park'], Folia Turistica, vol. 22, pp. 2534.

Sobala, M \& Myga-Piątek, U 2016, 'The optimization of rural landscape in the light of the idea of sustainable developmentthe example of Poland' Quaestiones Geographicae, vol. 35, no. 3, pp. 61-73.

SUIKZP 2015 - Studium Uwarunkowań, Kierunków i Zagospodarowania Przestrzennego Gminy Kościelisko 2015, [Study of conditions and directions of spatial planning of Kościelisko Commune], Kościelisko (Document Manuscript).

TNP 2020 - Statystyka, Tatrzański Park Narodowy [Statistics, Tatra National Park]. Available from: <https://tpn.pl/zwiedzaj/ turystyka/statystyka>. [4 May 2021].

Weber, M, Eisenführ, F \& Von Winterfeldt, D 1988, 'The effects of splitting attributes on weights in multiattribute utility measurement', Management Science, vol. 34, no. 4, pp. 431-445.

Wells, M \& Brandon, K 1992, People and parks: Linking protected area management with local communities, World Bank. World Wildlife Fund, U. S. Agency for International Development, Washington, DC.

Zhang, H \& Lei, SL 2012, 'A structural model of residents' intention to participate in ecotourism: The case of a wetland community', Tourism Management, vol. 33, no.4, pp. 916925. 